\title{
Acceptable words
}

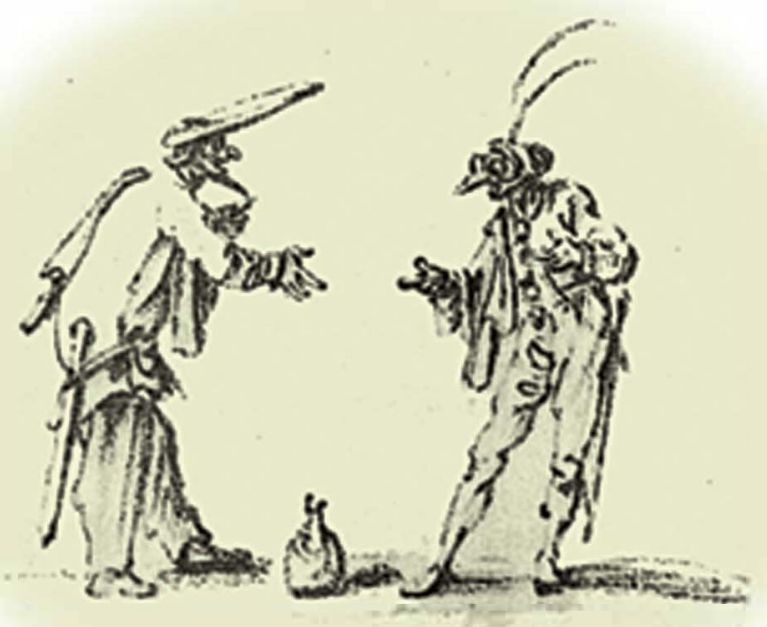

\section{Essays on the poetry of Geoffrey Hill}

Jeffrey Wainwright 


\section{Acceptable words}

\section{MANCHESTER 1824}

Manchester University Press 
Jeffrey Wainwright - 9781847793966

Downloaded from manchesterhive.com at $04 / 26 / 2023$ 12:57:55PM 


\title{
Acceptable words
}

Essays on the poetry of Geoffrey Hill

\author{
JEFFREY WAINWRIGHT
}

Manchester University Press

Manchester and New York

distributed exclusively in the USA by Palgrave 
Copyright (C) Jeffrey Wainwright 2005

The right of Jeffrey Wainwright to be identified as the author of this work has been asserted by him in accordance with the Copyright, Designs and Patents Act 1988.

Published by Manchester University Press

Altrincham Street, Manchester M1 7JA

www.manchesteruniversitypress.co.uk

\section{British Library Cataloguing-in-Publication Data}

A catalogue record for this book is available from the British Library

Library of Congress Cataloging-in-Publication Data applied for

ISBN 0719067545 bardback

EAN 9780719067549

First published 2005

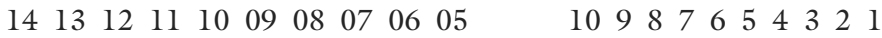

Typeset in Galliard by

D R Bungay Associates, Burghfield, Berks 